\title{
Usage of wing in ground effect to maintain lift force with reduced fuel consumption of aircraft
}

The main purpose of this article was to point out causes of reduced fuel consumption in aircraft jet engine when aircraft is in ground effect influence. Wing in ground effect occurs in the direct proximity of ground. The paper presents wing in ground effect description, with the numerical analysis of NACA M8 airfoil in three different conditions of flight. Numerical analysis was conduct in Ansys Fluent 17.2 software. The paper shows results of simulations which describes wing in ground effect influence on NACA M8 airfoil with two cases of jet engine exhaust gasses usage, first with exhaust gasses stream turns on upper airfoil surface, and second with exhaust gasses stream turns under lower airfoil surface. Results allow to define characteristics of NACA M8 airfoil in the influence of wing in ground effect which are lift coefficient, drag coefficient, drop of fuel consumption usage by the jet engine when lift force remains still in the wing in ground effect. The paper shows that in the wing in ground effect aircraft energy usage for flight in ground effect is smaller than for free air flight.

Key words: ekranoplan, numerical analysis, fuel consumption, jet engine, energy consumption

\section{Introduction}

When regular aircrafts fly at high altitude, there is a special kind which flies in the proximity of a ground. This kind of aircrafts is called "ekranoplan" and thanks to the wing in ground effect it makes great increase of aircraft lift force with reference to traditional aircrafts. WIG effect works in two ways, with positive angles of attack it makes lift force bigger in the proximity of ground, and for negative angles of attack, it makes greater downforce. Thus, WIG effect can be used in aeronautics, but also in automotive. The first ekranoplan was built by Rostislav Evgenievich Alexeyev in 1966, but in F1 WIG effect is present since 1979, where car front wing works in ground effect all the time.

WIG effect formation is simple, the most important factor is to reduce space between aircraft and ground. WIG effect provides to increase static pressure below the airfoil, what leads to the rise of lift force. Also, vortices made by higher pressure below and lower pressure above airfoil in WIG effect moves aside of wing tips, what provides to decrease of resistance and induced drag, also increases effective aspect ratio, what is shown in Fig. 1.
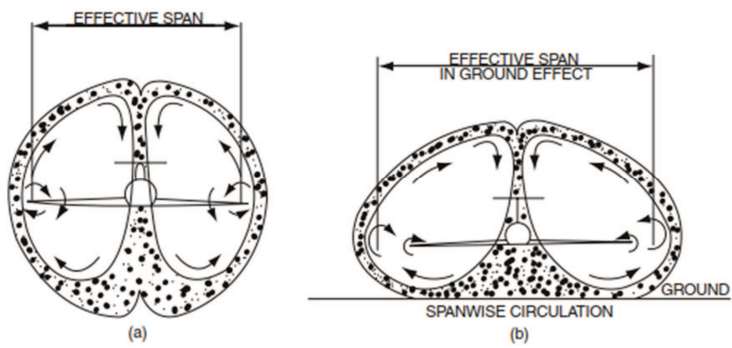

Fig. 1. Mechanism of WIG effect creation [1]

As it was written before, the most important factor, next to the angle of attack, is the height of flight. K.V. Rozhdestvensky [2] determines height coefficient for WIG crafts, this coefficient is the ratio of the height of flight above the sea level and length of airfoil chord. Moore N. [3], in his article about WIG effect wing geometry investi- gate that best value of height coefficient for WIG flight is 0,1 ; equation (1) shows height coefficient dependency:

$$
\overline{\mathrm{h}}=\frac{\mathrm{h}}{\mathrm{c}}
$$

where: $\overline{\mathrm{h}}$ - height coefficient; $\mathrm{h}$ - height of flight; $\mathrm{c}-$ length of airfoil chord.

\section{WIG effect airfoil geometry}

The most important part of every aircraft are wings, wing in WIG effect should provide high lift force and low drag force, but when aircraft operates in ground proximity airfoil should maximize static pressure under the wing. To choose right airfoil there was done series of numerical simulations for 10 different airfoils geometries [4]. The highest values of lift force were obtained for NACA M8 airfoil. Drag force for this profile was not the lowest one but the ratio of lift coefficient and drag coefficient which defines aerodynamic efficiency is biggest from investigated airfoils. For an optimal angle of attack $\left(6^{\circ}\right)$, when aerodynamic efficiency has the biggest value in WIG effect its value is equal to 16.56 . It means that aircraft on $1 \mathrm{~km}$ altitude can fly without engines $16.56 \mathrm{~km}$ until it touches the ground. To compare regular flight and WIG effect flight, the same airfoil in free stream flight has aerodynamic efficiency equal to 5.15 , so it is three times less. Influence of WIG effect is shown in Fig. 2 and in Table 1.

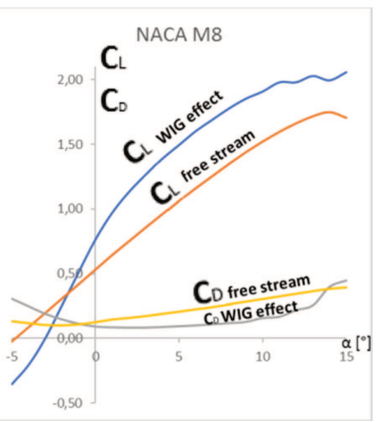

Fig. 2. Characteristics of NACA M8 profile [4] 
Table 1. Lift and drag coefficient values for NACA M8 profile [4]

\begin{tabular}{|c|c|c|c|c|}
\hline $\begin{array}{c}\text { Angle } \\
\text { of } \\
\text { attack } \\
\left.\alpha{ }^{\circ}\right]\end{array}$ & $\begin{array}{c}\text { Free stream } \\
\text { flight lift } \\
\text { coefficient }\end{array}$ & $\begin{array}{c}\text { WIG flight } \\
\text { lift coeffi- } \\
\text { cient }\end{array}$ & $\begin{array}{c}\text { Free stream } \\
\text { flight drag } \\
\text { coefficient }\end{array}$ & $\begin{array}{c}\text { WIG flight } \\
\text { drag coef- } \\
\text { ficient }\end{array}$ \\
\hline-5 & -0.02 & -0.36 & 0.13 & 0.31 \\
\hline-4 & 0.09 & -0.21 & 0.12 & 0.25 \\
\hline-3 & 0.2 & 0 & 0.11 & 0.19 \\
\hline-2 & 0.31 & 0.25 & 0.10 & 0.14 \\
\hline-1 & 0.42 & 0.51 & 0.11 & 0.11 \\
\hline 0 & 0.53 & 0.76 & 0.13 & 0.09 \\
\hline 1 & 0.64 & 0.97 & 0.15 & 0.08 \\
\hline 2 & 0.75 & 1.13 & 0.16 & 0.08 \\
\hline 3 & 0.86 & 1.26 & 0.17 & 0.08 \\
\hline 4 & 0.96 & 1.39 & 0.19 & 0.08 \\
\hline 5 & 1.06 & 1.49 & 0.21 & 0.09 \\
\hline 6 & 1.16 & 1.6 & 0.23 & 0.10 \\
\hline 7 & 1.25 & 1.69 & 0.24 & 0.11 \\
\hline 8 & 1.35 & 1.78 & 0.26 & 0.12 \\
\hline 9 & 1.44 & 1.85 & 0.28 & 0.13 \\
\hline 10 & 1.52 & 1.91 & 0.30 & 0.15 \\
\hline 11 & 1.6 & 1.98 & 0.33 & 0.16 \\
\hline 12 & 1.66 & 1.98 & 0.34 & 0.22 \\
\hline 13 & 1.72 & 2.03 & 0.36 & 0.25 \\
\hline 14 & 1.75 & 2 & 0.38 & 0.40 \\
\hline 15 & 1.7 & 2.06 & 0.39 & 0.45 \\
\hline & & & & \\
\hline
\end{tabular}

\section{Numerical analysis of WIG effect}

\subsection{ICEM CFD meshing software and models creation}

Models, which were used in numerical analysis, were created in Autodesk Inventor Professional 2017, CAD software. For every type of simulation were used one model, so there are 4 models. In Fig. 3. there is a model for free stream flight simulation, with the yellow dotted line is marked out boundaries for WIG effect flight. There is also the view of NACA M8 airfoil geometry. Dimensions:

- $\mathbf{c}$ is the length of airfoil chord $(3400 \mathrm{~mm})$

- $\quad \mathbf{b}$ is the height of domain for free stream simulation (9c)

- b' domains height for WIG effect simulation (2.5c)

- d distance between the front side of the domain and leading edge of the airfoil for free stream flight (5c)

- d' distance between the front side of the domain and leading edge of the airfoil for WIG effect flight (1.8c)

- e distance between the front side of the domain and trailing edge of the airfoil for free stream flight (6.5c)

- $\mathbf{h}$ height coefficient for WIG effect flight $(0.1 \mathbf{c})$

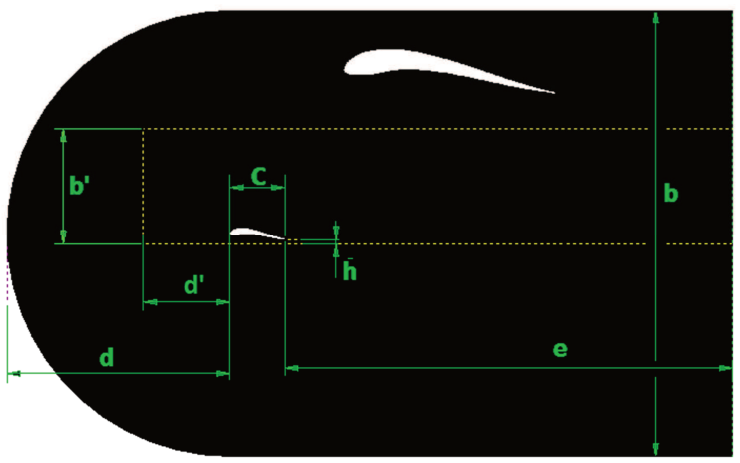

Fig. 3. Model created for simulation of free stream flight, with NACA M8 airfoil geometry
For every model, there were created a new structural 2D planar mesh in Ansys ICEM CFD meshing software. Every mesh is different, and the biggest difference is a number of cells. Mesh for free stream flight simulation has 19765 cells, mesh for WIG effect flight simulation has 35804 cells, mesh for WIG effect flight with exhaust gasses redirection above the airfoil has 29400 cells, mesh for WIG effect flight with exhaust gasses redirection to the lower surface of airfoil has 34344 cells and Fig. 4. shows display of this mesh. To create this kind of mesh, the first model should be divided into blocks, this creates edges on the surface. There is a possibility to set a number of elements for every edge on the surface, it is important to set the same number of element to parallel edges.

Also, in CFD simulation where turbulence equation is on, it is important to create boundary layer on important edges or surfaces. In this simulations, the first layer of cells on the airfoil has a height of $0,00032554 \mathrm{~mm}$. This height is calculated in $\mathrm{y}+$ calculator. $\mathrm{y}+$ or dimensionless wall distance (2) is bonded with turbulence model (in this case kepsilon) used in simulations, in this model of turbulence, $y+$ value should be between approximately 300-100 (in this simulation set as 100). Dimensionless wall distance equation:

$$
\mathrm{y}^{+}=\frac{\mathrm{u}_{* \mathrm{y}}}{\mathrm{v}}
$$

where: $\mathrm{u}_{*}$ - friction velocity; $\mathrm{y}$ - distance to the nearest wall; $v$ - kinematic viscosity

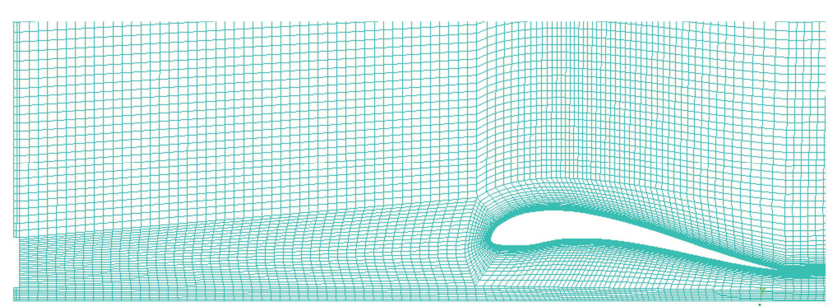

Fig. 4. View of mesh for WIG effect simulation with exhaust gasses redirection to the lower surface of airfoil

\subsection{ANSYS Fluent simulations boundary conditions} Simulation conditions for all cases:

- solver set as density-based because velocity in this simulation is set above 0.3 of Mach number, above this value, there is need to consider flow as compressible

- pressure value set as $1 \mathrm{~atm}(101325 \mathrm{~Pa})$

- energy equation set on

- turbulence model set as k-epsilon, and it contains two equations in it, first the turbulent kinetic energy $\mathrm{k}$, and second dissipation rate equation

- gas property set as ideal-gas, because the air in density based solver does not work with constant air density Boundary conditions:

- for every case edges of domain sets as pressure far-field condition, with two exceptions, first for surface below airfoil in wing in ground effect cases, where ground condition was set as moving wall, with the speed of movement of air stream velocity, second for outlet from jet engine, where condition is set as mass-flow-inlet 
(mass flow $66 \mathrm{~kg} / \mathrm{s}$, temperature $450 \mathrm{~K}$, initial gauge pressure $1.3 \mathrm{~atm}$, mass flow value is similar to value in F-100-PW-229 engine, from the nozzle behind last turbine stage - internal duct. The height of nozzle in 2D simulation is $600 \mathrm{~mm}$ )

- standard initialization for pressure far-field

- air stream velocity for free stream flight set as 0.4 of Mach number $(139 \mathrm{~m} / \mathrm{s})$, for WIG effect flight set as 0.373 of Mach number $(129.46 \mathrm{~m} / \mathrm{s})$, for both cases of exhaust gases redirection in WIG effect flight air stream velocity is set as 0.3 of Mach number $(104.13 \mathrm{~m} / \mathrm{s}$ )

In every simulation as the main condition of results, convergence is recognized stabilization of lift and drag coefficients in numerical analysis. It is shown in Fig. 5.
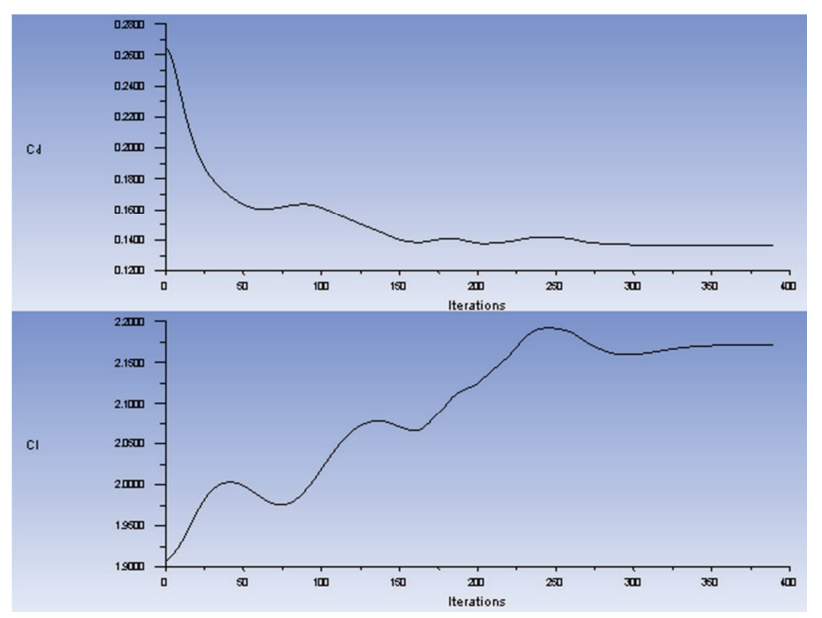

Fig. 5. Convergence of drag and lift coefficient

\section{Numerical analysis results}

To maintain lift force still in WIG effect flight it is necessary to reduce air stream velocity. Table 2 and Table 3. presents results of numerical simulations, as expected redirection of exhaust gasses in WIG effect above airfoil creates less lift force, but also less drag force. Even with smaller value lift force, as it is shown in Table 4. there is a big increase of lift coefficient for every case of WIG effect usage. With general thrust equation (3) it is possible to calculate thrust needed to propel aircraft, with values of thrust and on the assumption that thrust for free stream flight is $100 \%$ of jet engine power (F-100 engine), Table 5 presents needed thrust in the percentage of maximum engine thrust.

$$
\mathrm{K}=\mathrm{m}_{2} * \mathrm{~V}_{2}-\mathrm{m}_{1} * \mathrm{~V}_{1}
$$

where: $\mathrm{K}$ - thrust; $\dot{m}$ - air stream mass flow (2 - outlet; 1 - inlet); V - air stream speed

Table 2. Lift force values for NACA M8 profile

\begin{tabular}{|l|l|}
\hline Free air stream [N] & 51482 \\
\hline WIG effect [N] & 51529 \\
\hline WIG effect (exhaust gasses redirection above airfoil) [N] & 39261 \\
\hline WIG effect (exhaust gasses redirection below airfoil) [N] & 51609 \\
\hline
\end{tabular}

Table 3. Drag force values for NACA M8 profile

\begin{tabular}{|l|c|}
\hline Free air stream [N] & 1197 \\
\hline WIG effect [N] & 313 \\
\hline WIG effect (exhaust gasses redirection above airfoil) [N] & 2513 \\
\hline WIG effect (exhaust gasses redirection below airfoil) [N] & 3518 \\
\hline
\end{tabular}

Table 4. Lift and drag coefficient values for NACA M8 profile

\begin{tabular}{|l|c|c|}
\hline & $\begin{array}{c}\text { Lift (CL) } \\
\text { coefficient }\end{array}$ & $\begin{array}{c}\text { Drag (CD) } \\
\text { coefficient }\end{array}$ \\
\hline Free air stream [N] & 2.27 & 0.0528 \\
\hline WIG effect [N] & 5.26 & 0.0317 \\
\hline $\begin{array}{l}\text { WIG effect (exhaust gases redirec- } \\
\text { tion above airfoil) [N] }\end{array}$ & 6.08 & 0.389 \\
\hline $\begin{array}{l}\text { WIG effect (exhaust gases redirec- } \\
\text { tion below airfoil) [N] }\end{array}$ & 8.09 & 0.552 \\
\hline
\end{tabular}

Fig. 6. Shows absolute pressure distribution (measured relative to the absolute zero pressure), as expected pressure below the airfoil in WIG effect flight rises, this phenomenon provides to increase of lift force and lift coefficient but also, to decrease induced drag. In $\mathrm{C}$ section of Fig. 6. Pressure distribution for exhaust gasses redirection case below the airfoil is greater than in any other case.

Fig. 7. presents air stream velocity distribution around the airfoil in numerical simulations. With the rise of velocity in WIG effect flight, it is expected that air stream could create higher turbulences, what is possible to see after trailing edge in B section. Exhaust gasses in C-section creates high air speed area above the airfoil, what can provide to create a separation of the boundary layer.

Table 5. Thrust needed to propel aircraft

\begin{tabular}{|l|c|c|}
\hline Thrust for free air stream flight & $80 \mathrm{kN}$ & $100 \%$ \\
\hline Thrust for WIG effect flight & $74.24 \mathrm{kN}$ & $92.81 \%$ \\
\hline $\begin{array}{l}\text { Thrust for WIG effect flight with exhaust } \\
\text { gases redirection }\end{array}$ & $59.86 \mathrm{kN}$ & $74.82 \%$ \\
\hline
\end{tabular}

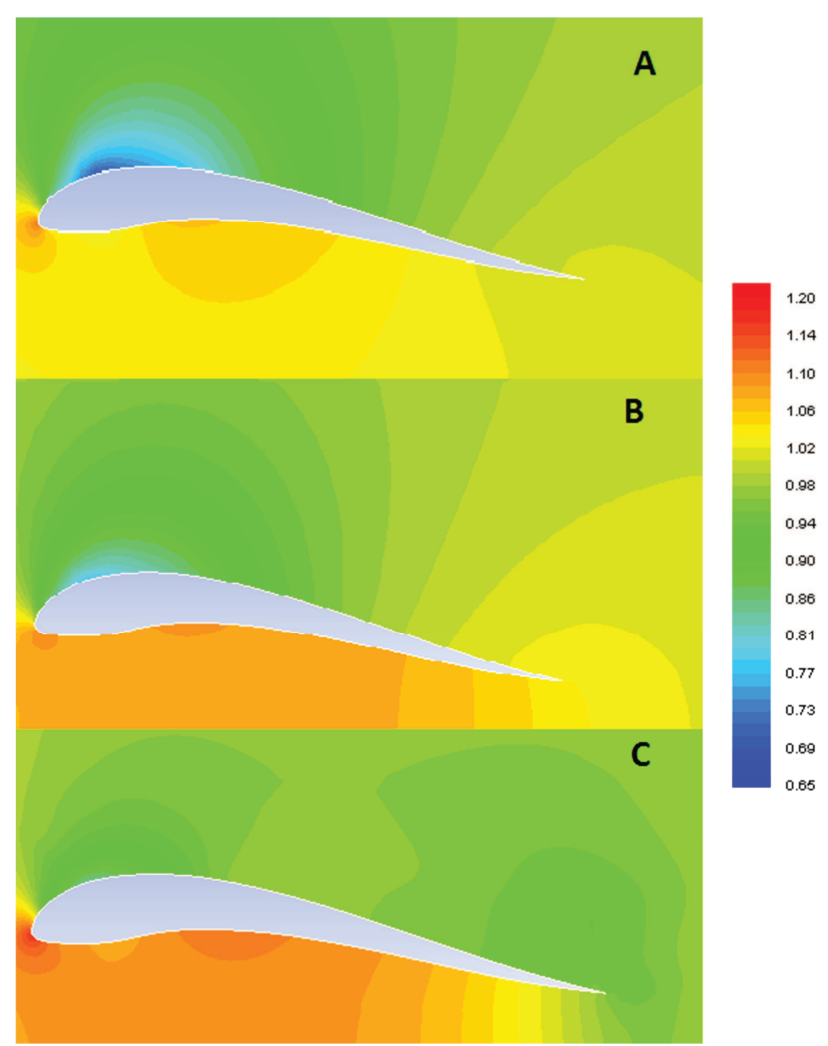

Fig. 6. Absolute pressure distribution: A - free stream flight; B - WIG effect flight; C - WIG with exhaust gasses redirection under airfoil [atm] 


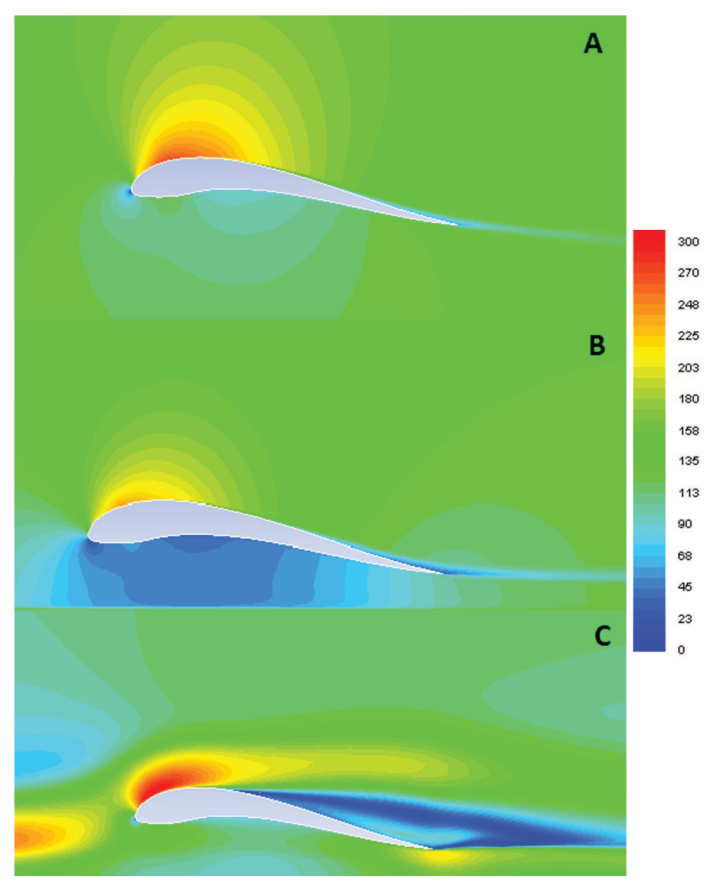

Fig. 7. Air velocity distribution: A - free stream flight; B - WIG effect flight; C - WIG with exhaust gasses redirection under airfoil $[\mathrm{m} / \mathrm{s}]$

Fig. 8 presents charts of specific fuel consumption rate in function of thrust, with flight in full power, which is 80 $\mathrm{kN}$, the engine burns $21.5 \mathrm{mg} /(\mathrm{s} \cdot \mathrm{N})$ of fuel. When the power to propel aircraft is smaller, like in WIG effect flight its need $21 \mathrm{mg} /(\mathrm{s} \cdot \mathrm{N})$ of fuel. When to increase lift force aircraft uses exhaust gasses specific fuel consumption rate drops below $20 \mathrm{mg} /(\mathrm{s} \cdot \mathrm{N})$.

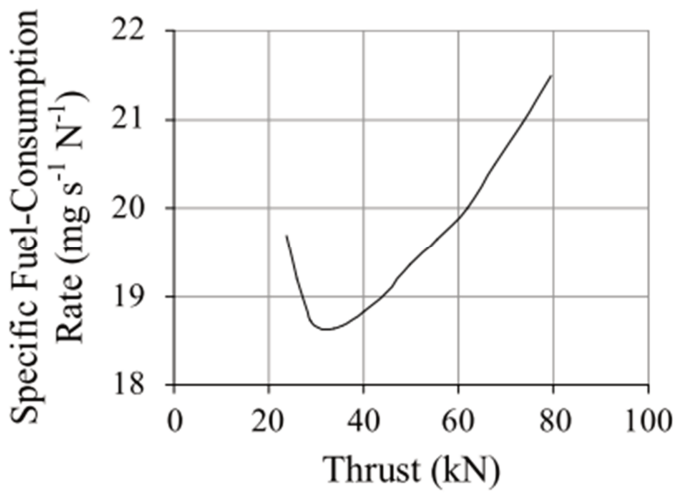

Fig. 8. The specific fuel consumption rate versus the thrust of F-100 jet engine [5]

\section{Conclusion}

WIG craft does not need a regular airports, it can start and takeoff from water. WIG effect produces more lift force what provides to less fuel consumption of aircraft, and it makes it cheaper. In automotive WIG effect is used to provide better traction. It makes both, automotive, and aeronautics safer, the stall of airfoil is not so catastrophic when it uses WIG effect. There is also a few disadvantages WIG effect produce more drag with negative angle of attack in automotive, particularly in F1, it cannot operate on the sea when waves are too high. It is important for aircraft to avoid negative angle attack, because it can provide to sudden lift force loss. It is necessary to conduct further research on WIG effect. NACA M8 profile is promising airfoil for WIG crafts.

\section{Nomenclature}

WIG wing in ground

\section{Bibliography}

[1] YUN, L., BLIAULT, A., DOO, J. WIG Craft and Ekranoplan, Springer. 2010.

[2] ROZHDESTVENSKY, K.V. Aerodynamics of a lifting system in extreme ground effect. $1^{\text {st }}$ ed., Springer-Verlag. 2000, 63-67.

[3] MOORE, N., WILSON, P.A., PETERS, A.J. An investigation into wing in ground effect airfoil geometry, School of

Adam Rojewski, MEng. - Faculty of Machines and Transport at the Poznan University of Technology.

e-mail: Adam.M.Rojewski@doctorate.put.poznan.pl

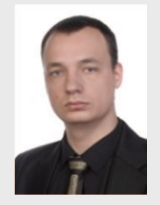

Engineering Sciences, University of Southampton, SO17 1BJ, UK 2002.

[4] ROJEWSKI, A. Ekranoplan - wstęp do projektu płatowca, MScEng Thesis, Poznan University of Technology, Poznan 2016.

[5] LEE, A.S., SINGH, R., PROBERT, S.D. Modelling of the performance of a F100-PW229 equivalent engine under sealevel static conditions. $45^{\text {th }}$ AIAA/ASME/SAE/ASEE Joint Propulsion Conference \& Exhibit, Denver, Colorado 2009.

Jarosław Bartoszewicz, DSc., DEng. - Faculty of

Machines and Transport at the Poznan University of Technology.

e-mail: Jaroslaw.Bartoszewicz@put.poznan.pl 